УДК $179.9+37.013 .73$

DOI https://doi.org/10.32837/apfs.v0i26.903

О. Г. Рогова

ORCID ID: 0000-0001-5498-6897

кандидат філософських наук, доиент, професор кафедри філософії

КЗВО «Дніпровська академія неперервної освіти» Дніпропетровської обласної ради»

\title{
ДУХОВНО-ЕТИЧНЕ ПІДІРУНТЯ ПРОТИСТОЯННЯ ЗАЗДРОСТІ ЯК ПРЕДМЕТ ФІЛОСОФСЬКО-ОСВІТНЬОГО АНАЛІЗУ
}

Вступ. Проблема боротьби добра і зла нині є дуже актуальною у філософсько-етичному дискурсі у зв'язку зі зростанням морального релятивізму, який не заперечує, а іноді й реабілітує вияви зла в сучасному суспільстві. Набуваючи великих масштабів, етичний негатив укорінюється в думках і вчинках, скорочуючи «простір» добра не тільки у дорослому світі, але і в середовищі підростаючого покоління.

3 урахуванням того, що будь-який етичний негатив спочатку народжується у внутрішньому світі людини, а потім вибухає ззовні, особливої уваги щодо його упередження заслуговують внутрішні етико-негативні стани, серед яких «почесне» місце займає заздрість. Розповсюдженню заздрості нині сприяють і засоби масової інформації, які підсилюють її загострення у суспільстві.

Успішні бізнесмени, політики й чиновники на екранах презентують себе зразками та вчителями життя. Вони не вважають за потрібне приховувати свої не завжди чесно зароблені надприбутки. Можна згадати і задоволених собою акторів, діячів естради, успішних спортсменів, захоплених своєю популярністю телеведучих і запальних діджеїв. Відбувається майже расистська сегрегація суспільства на успішних і невдах. Однак останні не збираються плакати, а відповідають здебільшого скаженою заздрістю щодо ситих і задоволених. Тому спалахують протести, виникає ворожнеча, конфлікти та інша соціальна нестабільність.

$\mathrm{y}$ протистояння будь-яким ціннісно-етичним негараздам великого значення набуває своєчасність їх упередження, а найоптимальнішим віком для цього є дитинство. Проте проблематика комплексного підходу щодо профілактики та протистояння заздрості на рівні становлення внутрішніх духовних якостей сучасної зростаючої особистості досить слабко рефлексується у сучасній філософії освіти.

Аналіз останніх досліджень і публікацій. Ще Платон з Аристотелем вважали заздрість людською вадою. Р. Декарт [1, с. 509] характеризував ії як «природне збочення», співвідносячи поняття заздрості із пристрастю. А. Шопенгауер [2, с. 126] зараховував заздрість до тих негараздів, які є підставою для людиноненависництва. І. Кант розглядав заздрість як порушення обов'язку перед собою та іншими [3, с. 229].
У дослідженнях XX ст. на увагу заслуговують твори I. Ільїна $[4 ; 5]$ та робота психотерапевта М. Кляйн «Заздрість і вдячність», у якій на підставі клінічного матеріалу розглядаються джерела виникнення заздрості у процесі реконструкції раннього дитячого розвитку [6]. Серед робіт останнього десятиліття соціально-психологічну природу заздрощів, механізми її актуалізації, фундаментальні передумови виникнення та їх вияви в міжособистісних стосунках у світлі філософсько-етичних праць аналізує Т. Бєскова [7]. Структуру детермінант заздрості, умови, етапи її виникнення та розвитку досліджує К. Базилян [8]. Важливою умовою розвитку особистості, яка протистоїть виявам заздрості, С. Яланська та В. Моляко важають саморегуляцію [9]. Подоланню деструктиву заздрощів у юнацькому віці на прикладі «Практикуму самопізнання» присвячена робота А. Васильченка [10].

Н. Ван де Вен із Тільбургського університету та його колеги М. Зіленберг і Р. Пітерс [11] наполягають на можливості переведення заздрості зі шкідливого формату (деструктивне зниження самооцінки) до доброякісного (мотивація на нові досягнення) 3 метою покращення етико-соціальної взаємодії. С. Протасі [12], вводячи нову таксономію заздрості, розглядає такі чотири іï типи: суперницьку, інертну, агресивну та злобну. Етичну можливість їі подолання він вбачає або у притисненні, або у перетворенні її у менш негативний тип заздрості. Проте ані конструктів, ані передумов такого подолання / обмеження заздрості жоден із авторів не наводить.

Сучасні духовні підходи щодо протистояння заздрості на рівні комунікативних процесів актуалізує I. Анаба [13], але вони здебільшого торкаються релігійно-містичних практик, що ускладнює (якщо не унеможливлює) їх застосування в освітній площині.

Отже, на тлі великої уваги науковців до теорій походження заздрості, варіативності її виявів, аналізу їі багатошаровості досить слабко рефлексується пошук тих фундаментальних етичних засад протистояння цьому внутрішньому відчуттю, які були б протиотрутою до заздрісних станів та які можна було б активно впроваджувати в освітньо-виховний процес. 
Мета дослідження. В межах цієї статті визначимо філософсько-освітні конструкти протистояння заздрості, спрямовані на формування особливого беззаздрісного стану внутрішнього світу особистості та шляхів його становлення, здатних допомогти сучасній зростаючій особистості у iï духовному розвитку. Мета конкретизується через такі завдання: здійснити аналіз найвідоміших теорій походження заздрості для накреслення конструктів її подолання; визначити оптимальні конструкти та основні принципи формування беззаздрісного стану особистості як складники розвитку її духовного світу; проаналізувати філософсько-освітні конструкти їх ефективного функціонування в межах експериментального дослідження.

Виклад основного матеріалу.

\section{1. Аналіз природної та соціальної концепцій походження заздрості}

У філософії заздрість здебільшого розглядається на трьох рівнях розвитку. На початковому етапі заздрість виявляється як усвідомлення своїх особистих недоліків або низького положення. На рівні емоційного переживання вона переростає у відчуття досади й злість. На третьому рівні (дієвому) етапі заздрість спрямовує індивіда на активну ворожнечу проти предмету чи об'єкта заздрості.

Для того, щоб зрозуміти, яким чином особистість може протистояти зростанню заздрості, необхідно розглянути найвідоміші теорії іï̈ походження. У цьому сенсі ми поділяємо думку багатьох науковців про дві найбільш поширені версії виникнення заздрості. За однією з них заздрість має природжену (природну) основу; за іншою вона виникає в процесі соціалізації. Згідно першої версії заздрість - це генетична програма, яка передається від попередніх поколінь і зміцнюється в процесі еволюції.

Прихильники природної теорії переконані у тому, що для наших пращурів основа заздрості полягала у конкуренції. Це був один із найдавніших механізмів індивідуального виживання. В. Леві $[14$, с. 81$]$ зазначає, що у суспільстві природна заздрісність має безліч соціальних і психологічних різновидів. Із віком вона не минує а, на його думку, просто маскується, «ховається» у глибині душі. Схожої позиції дотримується і Д. Медіна, який у книзі «Ген і сім смертних гріхів» [15] доводить, що чинити опір гріхам і боротися із заздрістю марно. Цю ваду можна пояснити відлунням тваринних інстинктів, які живуть у людській свідомості і можуть передаватися у спадок.

Прихильники теорії соціального походження вважають, що заздрість формується у процесі соціалізації, виникає під впливом оточуючого середовища шляхом порівняння особистості з іншими. Р. Шек [16, с. 251], називаючи заздрість «базовою антропологічною категорією», переконує, що вона є неусувним елементом людських стосунків, джерелом виникнення радикальних конфліктних рухів.

Спільні погляди мають І. Ільїн [5] і П. Куттер [17], які вважають, що одним із головних чинників формування заздрості є соціальне розшарування й усвідомлення людиною свого низького положення. На думку І. Ільїна, джерелом загостреної заздрості є абсолютна залежність незаможної людини від заможної. Він вважав, що на основі соціальної несправедливості спалахує масова заздрість, із якої народжується «доктрина безбожника», аморальності. Під впливом цієї вади відбувається деформація особистості: спочатку з'являється відчуття власної неповноцінності, потім - зростання озлоблення до ненависті.

П. Куттер, стверджуючи, що заздрість «виростає» на Ірунті соціальної несправедливості, упевнений, що вона призводить до усвідомлення неповноцінності свого існування та часто штовхає людину на здійснення аморальних вчинків. Ще одна причина заздрості - сприйняття більш успішного через власні невдачі і приниженого положення. Двигуном виникнення заздрості виступає класична тріада: пожадливість (заздрість до матеріальних досягнень), честолюбство (заздрість до кар'єри, владних повноважень) і пихатість (заздрість до нагород, популярності). До зовнішніх чинників, які сприяють заздрості, науковці відносять близькість у статусному положенні до об єкта заздрощів, що створює кращі умови для порівняння, дає більші оцінно досяжні можливості.

Серед причин появи заздрості уваги, на нашу думку, заслуговує визначення І. Ільїна: «Люди втрачають духовний хребет, одержимі заздрістю і жадністю" [4]; вони "розштовхують один одного, досягають «більшого», затоптуючи слабких i беззахисних» [4]. Відштовхуючись від проблематики духовної нерозвиненості сучасної зростаючої особистості, ми вважаємо, що більш глибинне розуміння походження заздрості (і більш дієві конструкти їі подолання) дає патристичне вчення.

\section{2. Біблійне і патристичне вчення про підвали-} ни заздрості

Біблійно-патристичне вчення будь-яку ваду здебільшого ототожнює із поняттям гріха, який $€$ порушенням домінантних моральних правил суспільного буття. Християнські богослови виділяють сім особливих гріхів, серед яких заздрість посідає місце однієї із найтяжчих людських вад. За християнським вченням, ангел через заздрість до Творця став нижчим за усіх істот, ізгоєм і чадом гніву Божого. «Заздрістю диявола смерть увійшла до світу» (Прем. 2, 24).

Перша людина схибила тому, що позаздрила, прислухавшись до спокусника (Бут. 3, 4-5). У стосунках дітей Адама і Єви заздрість призводить до 
братовбивства. Замість того, щоб упоратися із заздрістю або поставити її у певні межі, заздрісник влаштовує навколо себе зону смерті, яка є небезпечною і тим, кому він заздрить, і йому самому. У подальшій біблійній історії це показано із вражаючою наочністю. Із заздрості проти Мойсея спалахує низка заколотів, через які гинуть тисячі людей. Авесалом, бажаючи царської влади, піднімає бунт проти батька Давида й розв'язує громадянську війну.

Найстрашніший злочин світової історії розп'яття Христа - безпосередньо пов'язаний із заздрістю до Нього з боку верхівки Ізраїлю. Навіть після воскресіння Христового переслідування християн багато в чому були пов'язані із заздрістю: «Первосвященик і усі його прибічники iз садукейської течії наповнилися заздрощами, наклали руки на апостолів і посадили їх у громадську в’язницю» (Дії. 5, 17-19). Апостольські ж настанови насичені попередженнями берегти-

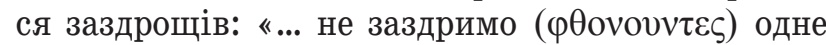
одному" (Гал. 5, с. 26). У хворих на постійні суперечки «виникають заздрість ( $ө$ оvо $)$, сварки, зневага, лукаві підозри» (1 Тим. 6,4$)$.

У патристичних працях підкреслюється, що серед усіх пристрастей, тобто почуттів, які повністю захоплюють особистість, немає згубнішої, ніж заздрість, яка роз'їдає душу подібно до того, як іржа роз'їдає залізо. Основними морально-психологічними чинниками, які породжують заздрість, 3 погляду християнських мислителів є гордість та егоїзм. Святитель Іоанн Златоуст у тлумаченні Гал. 5, 19-21 говорить, що «справи плоті очевидні, а саме: перелюб, розпуста, аморальність, безсоромність, ідолослужіння, чародійство, ворожнеча, сварки, заздрощі» [18].

Той же термін $ө \theta$ оvо означає заздрість у Словах святителя Григорія Богослова. Так у Слові

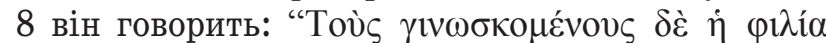

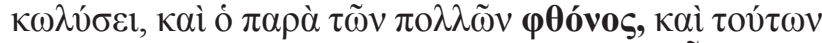

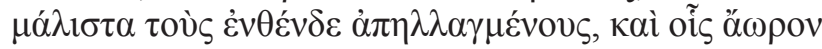

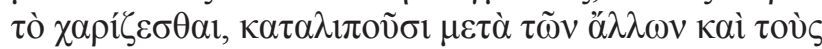

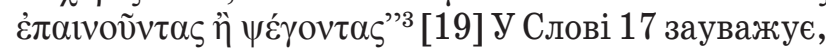

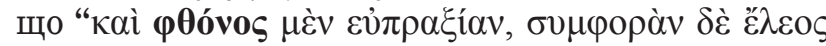

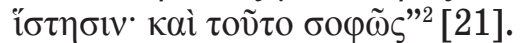

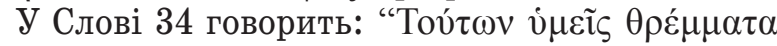

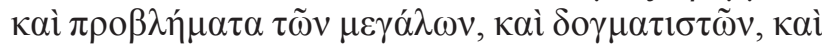

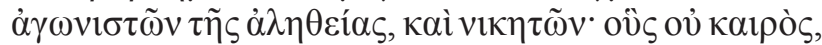

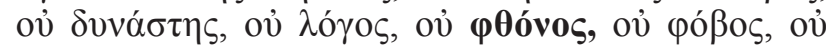

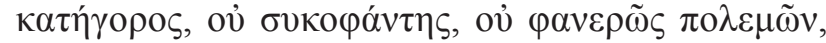

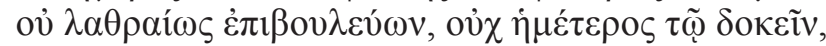

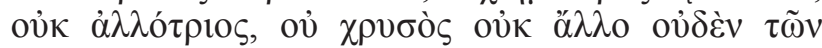

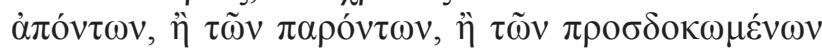

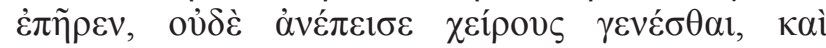

\footnotetext{
${ }^{1}$ «... ужели наша любовь и зависть ( препятствуют хвалить знаемых, особенно тех, которые уже переселились от нас, которым и льстить уже поздно» [20].

2 «... зависть ( $ө$ өоvo $)$ полагает преграду счастью, а милосердие - несчастью» [22].
}

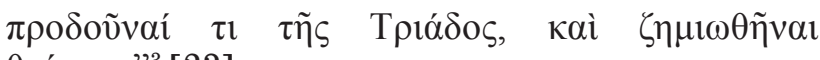
$\theta \varepsilon$ ó $\eta \tau \alpha " 3$ [23].

\section{3. Визначення етичної категорії афтонії та іï} складників

У біблійній і філософсько-патристичній спадщині наголошено, що протистояння заздрості перебуває у площині духовного становлення. Ми визначимо протилежну заздрості етичну категорію - афтонію ( $\dot{\varphi} \varphi$ өоví $)$, яка має інтегральний характер і відображає гармонійний, душевноспокійний внутрішній стан із відсутністю бажання не лише перерозподілити якийсь ресурс на власну користь, а й із формуванням навичок від «не сумувати від успіхів іншого» до «радіти за успіхи іншого». Зауважимо, що термін $\alpha \varphi \theta o v i ́ \alpha$ використовував ще Платон у діалозі «Протагор» (327b). Етичним наповненням афтонії вважаємо такі складники: доброзичливість, вдячність, співрадість, співстраждання, повага до оточуючих, великодушність, уміння бути задоволеним тим, що маєш.

Доброзичливість. Бути відкритими і уважними до оточуючих, готовими допомогти і підтримати, щиро радіти чужим перемогам означає бути доброзичливими. Здається, що бажати добра іншим природно і це не вимагає якихось особливих зусиль. Але в ситуаціях, коли людське его чіпляють за живе, буває досить непросто залишитися на позиції доброзичливості. Здатність щиро бажати добра людям незалежно від досвіду спілкування 3 ними - результат величезної внутрішньої роботи духу. Щоб змінити своє ставлення до людини, спочатку необхідно розібратися у собі, проаналізувати і переоцінити власні думки і переживання стосовно іншого. Завдяки цьому аналізу людина стає здатною до усвідомленого вибору у бік благого наміру.

Закладати основи доброзичливості краще 3 дитинства, навчаючи дитину пошукам доброго у людині. Це початок формування доброзичливості, яка допоможе сприймати переваги інших як приклад, а не особистий програш. Побажання добра буде загартовувати вміння володіти своїми емоціями і свідомо керувати думками, що сприятиме подоланню заздрості до інших. Коріння доброзичливості полягає у смиренні.

Уління бути задоволенил тил, що маєш. Ця антизаздрісна позиція передбачає оволодіння навичками зміни кута зору. Здебільшого заздрість виникає тільки з приводу того, до чого у людини $є$ певний інтерес, що вона високо цінує і в чому у неї є потреба. Замість постійних роздумів про те, чого

\footnotetext{
«Вы питомцы и порождения этих великих и наставников, и подвижников истины, и победителей, которых ни время, ни властелин, ни слово, ни зависть ( $\varphi$ оо о $\varsigma)$, ни страх, ни обвинитель, ни клеветник, ни явный враг, ни тайный наветник, ни кажущийся нашим, ни чужой, ни золото, ни все прочее, и отсутствующее, и настоящее, и ожидаемое не подвигло и не убедило сделаться худшими, изменить в чем-нибудь Троице и повредить учение о Божестве» [24].
} 
людині не вистачає, можна поміркувати про те, як їй добре порівняно з багатьма іншими людьми (хворими, знедоленими). Необхідно змінити ракурс із позиції «моє життя не ідеальне» на принцип «мені точно є чому радіти» (любляча родина, справжні друзі, здоров'я, закордонна відпустка). Можливо, усього цього більшості бракує, але існує кілька речей, про які варто собі нагадувати й бути вдячними за це щодня.

Такий підхід здатний поступово сформувати помірність, цінність якої визначається тим, що людина почуває себе спокійно, навіть у тих випадках, коли змушена задовольнятися найменшим. Причому готовність обмежитися за потреби природнім і необхідним є тільки умовою, яка забезпечує незалежність особистості від впливу зовнішнього світу й допомагає гармонізувати стосунки між людьми, насамперед через усунення заздрості. Наслідком цього, на думку С. Протасі [12, с. 23], може бути підвищення самооцінки людей i їх спонукання до розгляду ситуацій, відкритих до покращення.

Однією з головних внутрішніх фундацій афтонії є почуття вдячності. Вдячність - це найбільш потужний фактор, здатний пом'якшувати деструктивні імпульси заздрості, «підриваючи» iii коріння. Здатність до вдячності мінімізує заздрість, оскільки вона є підгрунтям для оцінки «добре» в собі та в інших людях. Знецінення ж того, що маєш, породжує заздрість. Для того, щоб особистість із стану заздрощів перейшла у стан вдячності, їй необхідно допомогти зрозуміти, що ніхто не перевершує нікого, бо кожен є цінним сам по собі і має працювати над собою, а не збирати атрибути першості.

Вдячності присвячено небагато досліджень. Більшість із них - релігійного характеру, які здебільшого обмежуються тлумаченням біблійної притчі про десять хворих на проказу, зцілених Ісусом Христом, із яких один повернувся, щоб подякувати. Проте вдячність має бути звичайним явищем не лише релігійного життя, а й удосконалювати будь-яку людину.

Беззаздрісне ставлення до іншого може виявлятися в різних формах дієвого співчуття - як співстраждання в ситуації лиха, так і співрадощів у ситуації благополуччя. Необхідно зазначити, що цим формам співчуття у науковій літературі приділялася неоднакова увага. Якщо співстраждання $є$ предметом розгляду багатьох філософськоетичних досліджень, то аналіз співрадощів не викликає великої уваги з боку дослідників.

Такий крен досліджень поведінки в «жалісливий» бік зумовлений кількома обставинами: впливами традиції досліджень у цьому напрямі; більш детально дослідженою феноменологією дистресу (неблагополуччя); необхідністю співстраждання 3 огляду на його доцільність, «непотрібність», «надмірність» співрадощів. Подібна «надмір- ність» продиктована тією обставиною, що радість з приводу успіху ближнього, на перший погляд, не $є$ життєвою необхідністю для людини, такою, як співстраждання, від вияву якого залежить благополуччя, а іноді й життя.

Особистісно-смислова природа співрадощів полягає, на нашу думку, не лише у сфері емпіричних побудов, а й у сфері духовних прозрінь. «Чужа радість так само, як своя» - формула співрадощів, яка розкриває їх центральний механізм - ідентифікацію з іншим як антизаздрість до успішного та щасливого. Проте лише цього механізму не досить, людині необхідне надзвичайно розвинене етичне відчуття, яке відкидає власний егоїзм. Саме християнська етика, що відобразила і сформулювала багатовіковий досвід психокорекції для боротьби людини із заздрістю, пропонує «духовний щит»таке ставлення до іншого, за якого його цінність сприймається, як своя. Виявом такого ставлення і є співрадість як корегуючий засіб подолання егоцентризму і руйнівної сили заздрості.

Що стосується поваги до оточуючих, то вона має бути не результатом стосунків, а фундаментом будь-яких можливих відносин, якісної взаємодії. Коли в особистості є чітке усвідомлення, що вона зобов'язана поважати усіх людей апріорі, повага до них є лише віддзеркаленням поваги до себе, то в будь-якому спілкуванні, особливо в конфліктному (а заздрість є однією із форм конфлікту), кожен буде орієнтований на вияв поваги, на пошук точок зіткнення, способу примирення, конструктивного рішення в будь-якій ситуації, а не на помсту на підставі заздрощів.

Насамперед повага виявляється як емоційна компетентність у спілкуванні з іншими. Людина не завжди має рацію, але завжди має право на власні думки, відчуття, емоції. Чому ж тоді так легко виявляти неповагу замість поваги? Здебільшого це пов'язано з тим, що ми звикли оцінювати і судити людей на основі певних стереотипів. Неповага також підкріплюється переконанням, що інші відповідають за наші відчуття. Ми навряд чи усвідомлюємо, що це не вони «образили» нас, що це ми образилися. Причому поважати людину не означає приймати усі їі вчинки: лютість, зраду тощо. Неприйнятна і неприємна поведінка іншого залишається такою, якою вона є. Але саме на тлі поваги до людини як абсолютної цінності простіше сказати їй правду без приниження або залишатися до неї уважним навіть під час сварки. Це кращий клімат для вирішення загальних проблем на грунті заздрості.

Коли ми називаємо людину великодушною, то характеризуємо їі як поблажливу, поступливу, здатну взяти до уваги інтереси інших людей, навіть тих, хто не цілком цього заслуговує з чиєїсь точки зору. Тому великодушність здебільшого позитивно оцінюється у людському суспільстві. 
Це не дивно, оскільки кожен випробовує вдячність до людей, які можуть закрити очі на те, чого самі не розділяють. Виявляти цю особливу якість може будь-яка людина, якщо вона це робить свідомо. Це набагато складніше, ніж виявити великодушність у пориві позитивних емоцій. Великодушність «народжується» 3 емпатії до інших.

I. Анаба у книзі «Подолання духу заздрості» [13] вважає, що не можливо позбутися заздрості без руху від припинення звинувачень тих, хто зробив боляче, до прощення й відкриття у собі любові до ближнього. Великодушність більше властива людям із високим рівнем духовного розвитку, оскільки вона вимагає глибшого розуміння себе і світу. Чим глибше це розуміння, тим легше набути великодушного стану, наслідком чого є подолання заздрості.

4. Експериментальна апробація формування складників афтонії

Існуюча недостатня розробленість проблематики становлення афтонії у практичній площині стала поштовхом для дослідження шляхів її плекання в освітній царині на підставі викладених теоретичних положень під час науково-дослідного освітнього експерименту за темою «Створення системи розвитку аксіосфери особистості на засадах традиційних духовних цінностей». До запропонованої тематики дослідження було залучено 42 освітні заклади Дніпропетровщини у період із 01.09.2013 по 01.09.2020 (науковий керівник к. філос. н. О.Г. Рогова).

Експериментальним закладам освіти на вибір було запропоновано три напрями реалізації завдань щодо формування аксіосфери зростаючої особистості: філософсько-світоглядний, культуроцентричний і релігійно-гуманістичний.
У кожному із напрямів серед інших показників ціннісного становлення пропонувалося засвоєння складників комплексного поняття «афтонії». Після закінчення діагностико-концептуального та формувального етапів експерименту (у 2015 та 2018 роках) було здійснено рефлексію над поточними результатами експерименту.

Від навчального закладу пропонувалася оцінити динаміку становлення афтонії в учнів експериментальних шкіл координатору експериментальної роботи, представнику адміністрації та класному керівникові за позиціями, які є складниками афтонії. Пропонувалася така оцінна шкала: зміни є докорінними; змін більше, ніж на 50\%; зміни приблизно на $50 \%$; змін менше, ніж на $50 \%$; зміни малопомітні, але є; позитивні зміни відсутні.

Результати анкетування узагальнені у Табл. 1, де кц - культуроцентричний напрям; фс - філософсько-світоглядний; рг - релігійно-гуманістичний.

Проведене анкетування спонукає до певних висновків. Якщо звернути увагу на якість отриманих результатів (зміни є докорінними; змін більше, ніж на $50 \%$;), то приблизно однаково ефективними напрямами виявилося формування поваги до оточуючих: культуроцентричний (далі - кц) $40 \%$, релігійно-гуманістичний (далі - рг) - 38\%, філософсько-світоглядний (далі - фс) - 40\% ; великодушності: кц $-40 \%$; рг $-43 \%$; вміння бути задоволеним тим, що маєш: кц $-30 \%$; фс $-30 \%$; розуміння того, що подолання заздрощів полягає у духовній площині: кц $-40 \%$; рг $-39 \%$.

Пріоритетно ефективним виявився культуроцентричний напрям у формуванні вдячності $(60 \%)$ проти $30 \%$ фс і $43 \%$ рг; доброзичливості $(70 \%)$ проти $60 \%$ фс і $42 \%$ рг; здатності до співчуття (60\% ) проти $50 \%$ фс і $48 \%$ рг. Пріоритетно

Таблиця 1

\begin{tabular}{|c|c|c|c|c|c|c|c|c|c|c|c|c|c|c|c|c|c|c|}
\hline & \multicolumn{3}{|c|}{$\begin{array}{c}\text { 3міни є } \\
\text { докорінними } \\
(\%) \\
\end{array}$} & \multicolumn{3}{|c|}{$\begin{array}{c}\text { 3мін більше, } \\
\text { ніж на 50\% } \\
(\%)\end{array}$} & \multicolumn{3}{|c|}{$\begin{array}{c}\text { 3міни приблизно } \\
\text { на 50\% } \\
\text { (\%) }\end{array}$} & \multicolumn{3}{|c|}{$\begin{array}{l}\text { 3мін менше, } \\
\text { ніж на 50\% } \\
(\%)\end{array}$} & \multicolumn{3}{|c|}{$\begin{array}{c}\text { Зміни } \\
\text { малопомітні, } \\
\text { але є (\%) }\end{array}$} & \multicolumn{3}{|c|}{$\begin{array}{l}\text { Зміни } \\
\text { відсутні } \\
(\%)\end{array}$} \\
\hline & кц & фc & рг & кц & фc & рг & кц & фc & рг & кц & фc & рг & кц & $\phi c$ & $\mathrm{p} \Gamma$ & кц & $\phi c$ & рг \\
\hline Доброзичливість & 10 & & 5 & 60 & 60 & 38 & 30 & 30 & 38 & & 10 & 19 & & & & & & \\
\hline Вдячність & 10 & & & 60 & 30 & 43 & 10 & 40 & 28 & 20 & 20 & 24 & & 10 & 5 & & & \\
\hline $\begin{array}{l}\text { Вияви поваги } \\
\text { до оточуючих }\end{array}$ & & & & 40 & 40 & 38 & 50 & 40 & 43 & 10 & 20 & 19 & & & & & & \\
\hline Великодушність & & & 5 & 40 & 10 & 38 & 50 & 50 & 19 & 10 & 30 & 29 & & 10 & 9 & & & \\
\hline $\begin{array}{c}\text { Здатність } \\
\text { до співрадощів }\end{array}$ & & & 5 & 20 & 10 & 29 & 80 & 30 & 38 & & 50 & 19 & & & 9 & & & \\
\hline $\begin{array}{c}\text { Здатність } \\
\text { до співстраждання }\end{array}$ & 10 & & 15 & 50 & 50 & 33 & 40 & 30 & 33 & & 10 & 19 & & 10 & & & & \\
\hline $\begin{array}{c}\text { Вміння бути } \\
\text { задоволеним тим, } \\
\text { що маєш } \\
\end{array}$ & & & & 30 & 30 & 19 & 60 & 40 & 29 & 10 & 20 & 38 & & 10 & 9 & & & 5 \\
\hline $\begin{array}{c}\text { Розуміння того, що } \\
\text { подолання заздрощів } \\
\text { полягає у духовній } \\
\text { площині }\end{array}$ & 10 & & 15 & 30 & 30 & 24 & 30 & 40 & 38 & 40 & 20 & 14 & & & 9 & & & \\
\hline
\end{tabular}


ефективним виявився релігійно-гуманістичний напрям у формуванні здатності до співрадощів $(34 \%)$ проти $20 \%$ кц та $10 \%$ фс.

Таким чином, більш ефективним напрямом формування афтонії виявився культуроцентричний. Це можна пояснити тим, що розкриття глибинного духовного підгрунтя афтонії засобами культури у шкільному віці є більш переконливим, ніж безпосереднє розкриття положень християнської етики, засвоєння яких потребує більшого досвіду й запиту до духовного життя, який у шкільному віці є досить слабко сформованим (за виключенням учнів, які мають релігійне виховання у родинах).

Висновки. Аналіз концепцій, які досліджують проблему виникнення заздрості, дозволив зробити висновок про те, що заздрість формується на основі людського егоїзму, гордовитого порівняння, а також на грунті соціальної несправедливості та є виявом внутрішнього стану, при якому чиїсь реальні або уявні переваги суб’єкт сприймає як загрозу цінності власного «Я», і тому супроводжується афектними переживаннями і діями, що несуть у собі руйнівний сенс як для себе, так і для оточуючих.

Оскільки людина своїми думками і вчинками породжує у собі заздрість, то тільки вона здатна їі подолати, змінивши думки, ставлення до інших, цінності на рівні її духовного життя шляхом формування комплексу антизаздрісних чеснот (афтонія) на таких конструктах як рефлексія та уникнення постійного порівняння, відчуття власної гідності і впевненості у своїх силах, духовне самоудосконалення. Для цього необхідно формувати в особистості, яка зростає, такі чесноти як доброзичливість, вдячність, співрадість і співстраждання, повага до оточуючих, великодушність, вміння бути задоволеним тим, що маєш, на грунті розуміння того, що плекання афтонії полягає у духовній площині.

\section{Jimepamypa}

1. Декарт Р. Сочинения: в 2 т. / под ред. В.В. Соколова. Москва : Мысль, 1989. Т. 1. 654 с.

2. Шопенгауэр А. Об основе морали. А. Шопенгауэр. Свобода воли и нравственность. Москва : Республика, 1992. С. 14-256.

3. Кант И. Основы метафизики нравственности. И. Кант. Сочинения: в 6 m. Москва : Мысль, 1965. T. $4.544 \mathrm{c}$.

4. Ильин И. Зависть как источник бедствий. Ильин И. Собрание сочинений: в 10 т. / сост., вступит. ст. и коммент. Ю.Т. Лисицы. Т. 2. Кн. 2: Наши задачи: статьи, 1951-1954 гг. Москва : Русская книга, 1993. 480 c. URL: http://libbabr.com/?book=2815 (дата звернення: 11.11.2020).

5. Ильин И. Путь духовного обновления. Москва : ACT, 2006. $366 \mathrm{c}$.

6. Кляйн М. Зависть и благодарность. Исследование бессознательных источников / пер. с англ. Информационный центр психоаналитической культуры Санкт-Петербурга. Санкт-Петербург : Б.С.К., 1997.
URL: https://www.psychol-ok.ru/lib/klein/zib/zib_06. html (дата звернення: 10.11.2020).

7. Бескова Т.В. Особенности проявления зависти в межличностном взаимодействии субъектов. Известия Самарского научного иентра Российской акаделии наук. № 5(37). 2010. С. 103-109.

8. Базилян К. Генезис та психологічні механізми виникнення заздрості: теоретичний аналіз. Науковий блог. Національний університет «Острозька академія». URL: https://naub.oa.edu.ua/2014/henezysta-psyholohichni-mehanizmy-vynyknennya-zazdrostiteoretychnyj-analiz/ (дата звернення: 02.10.2020).

9. Яланська С., Моляко В. Психологія протистояння конструктивного та деструктивного : монографія. Полтава: Сімон, 2018. 111 с.

10. Васильченко А.В. Психологічна профілактика та подолання заздрощів у юнацькому віці (на прикладі «практикуму самопізнання»). Науковий вісник Херсонського державного університету. Серія: Психологічні науки. 2014. Вип. 1(1). С. 134-139.

11. Van de Ven N., Zeelenberg M., Pieters R. (2009). Leveling Up and Down: The Experiences of Benign and Malicious Envy. Emotion. 9(3). URL: https://www.researchgate.net/publication/26256430 (Last accessed: 01.11.2020).

12. Protasi S. Varieties of Envy. Philosophical Psychology."2016. № 29(4). P. 535-549 / PhilArchive. P. 1-28. URL: https://philpapers.org/archive/PROVOE. pdf (Last accessed: 01.11.2020).

13. Anaba E. Overcoming The Spirit Of Envy. Accra: Arrow editing services. 2012. 224 p. URL: https://books. google.com.ua/booksid=i2B0JbxZgxsC\&printsec $=$ fro ntcover\&hl $=\mathrm{ru} \# \mathrm{v}=$ onepage $\& \mathrm{q} \& \mathrm{f}=$ false (Last accessed: 02.11.2020).

14.Леви В.Л. Искусство быть другим. Москва : Знание, 1980. 208 с.

15. Medina John J. The Genetic Inferno: inside the Seven Deadly Sins. Cambridge University Press. July 19, 2012. 356 p.

16. Шёк Г. Зависть. Теория социального поведения. Москва : Мысль; ИРИСЭН, 2010. 544 с.

17. Куттер П. Любовь, ненависть, зависть, ревность. Психоанализ страстей / пер. С. Панкова. СанктПетербург : Б.С.К, 2004. 120 с.

18. Толкования на Гал. 5:19. Толкования Священного Писания. URL: http://bible.optina.ru/new:gal:05:19 (дата звернення: 04.11.2020).

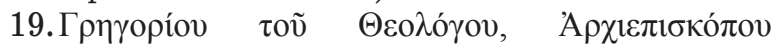

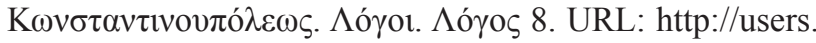
uoa.gr/ nektar/orthodoxy/paterikon/grhgorios_8eologos_ logoi.htm\#8 (дата звернення: 04.11.2020).

20.Григорий Богослов, свт. Слово 8. Собрание творений. В 2 т. / Пер. Моск. дух. акад. Мінськ : Харвест. Москва : АCT, 2000. T. 1. Слова. 832 с. URL: https://azbyka.ru/otechnik/Grigorij_Bogoslov/slovo/8 (дата звернення: 04.11.2020).

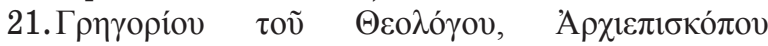

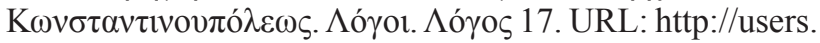
uoa.gr/ nektar/orthodoxy/paterikon/grhgorios_8eologos_ logoi.htm\#17 (дата звернення: 04.11.2020).

22.Григорий Богослов, свт. Слово 17. Собрание творений. В 2 т. / Пер. Моск. дух. акад. Мінськ : Харвест. Москва : АCT, 2000. T. 1. Слова. 832 с. URL: 
https://azbyka.ru/otechnik/Grigorij_Bogoslov/ slovo/17 (дата звернення: 05.11.2020).

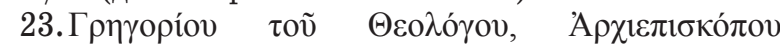

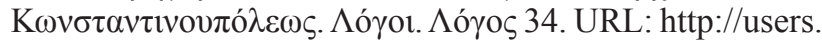
uoa.gr/ nektar/orthodoxy/paterikon/grhgorios_8eologos logoi.htm\#34 (дата звернення: 04.11.2020).

24. Григорий Богослов, свт. Слово 34. Собрание творений. В 2 т. / Пер. Моск. дух. акад. Мінськ : Харвест. Москва : АCT, 2000. Т. 1. Слова. 832 с. URL: https://azbyka.ru/otechnik/Grigorij_Bogoslov/ slovo/34 (дата звернення: 05.11.2020).

\section{Анотація}

Рогова О. Г. Духовно-етичне підгрунтя протистояння заздрості як предмет філософсько-освітнього аналізу. - Стаття.

У статті розглянуто проблематику протистояння заздрості крізь призму формування внутрішніх духовних якостей сучасної зростаючої особистості. Дослідження здійснено в контексті потреб сучасної української духовно-етичної та філософсько-освітньої думки.

Метою статті є визначення тих потенційних освітніх можливостей, які можуть відкрити особистості, яка зростає, шляхи формування особливого внутрішнього беззаздрісного стану особистості та траєкторій його становлення, здатних допомогти сучасній зростаючій особистості у її духовному розвитку. Методологічною базою дослідження є поєднання системного, герменевтичного, історико-соціокультурного, компаративного аналізу та методу соціологічного опитування.

Розглянуто найпоширеніші теорії виникнення заздрості: природну, соціальну та патристичну. Наслідком цього стало визначення інтегрального поняття «афтонія» як особливого внутрішнього стану беззаздросності, що відображає гармонійний, душевно-спокійний устрій з відсутністю бажання не лише перерозподілити якийсь ресурс на свою користь, а й із формуванням навичок від «не сумувати від успіхів іншого» до «радіти за успіхи іншого». Етичним підгрунтями афтонії визначено такі складники: доброзичливість, вдячність, співрадість, співстраждання, повага до оточуючих, великодушність, вміння бути задоволеним тим, що маєш.

Аналіз поняття «афтонія» 3 огляду на його походження з релігійно-етичної сфери східно-європейської культури й неможливість його виникнення без участі самої особистості дозволив зробити крок від патристичної спадщини до сучасних освітніх завдань. Окреслено окремі філософсько-освітні напрями формування афтонії, запропоновані в межах освітнього експерименту шляхом: 1) включення філософсько-світоглядних освітніх конструктів формування беззаздросності; 2) засвоєння духовно-ціннісного сенсу антизаздрості засобами культуроцентричної освіти; 3) впровадження релігійно-гуманістичного підходу до викладання навчальних курсів християнсько-етичного спрямування з їх вченням про беззаздрісність. Усі зазначені напрями дозволяють поширити афтонію з теорії площини на простір життєбудівництва. Визначено, що формування етичного концепту афтонії засобами культуроцен- тричного підходу через розкриття його аксіологічного потенціалу в освітній царині виявилося більш ефективним порівняно із двома іншими напрямами експериментальної діяльності.

Ключові слова: заздрість, цінності, духовний розвиток, зростаюча особистість, освітній експеримент.

\section{Summary}

Rohova O. G. Spiritual-ethic basis of overcoming of the envy as a subject of philosophical-educational analysis. - Article.

In the article is considered the problem of struggle against envy as the formation of internal spiritual qualities of the modern growing personality. The research is carried out in the of queries of the modern Ukrainian spiritually ethics and philosophical-educational thought of the needs of modern Ukrainian spiritual, ethical and philosophical and educational thought.

The aim of this article is to determine those potential educational possibilities that can open for growing personality ways to form its special inner unenviable state and trajectories of its formation, that can help for modern growing personality in its spiritual development. The methodological base of research is combination of the system, hermeneutics, historical and sociocultural, comparative methods and sociological questioning.

Are considered the most common theories of nascence of the envy: natural, social and patristic. The result was the definition of the integral concept of "aphthony" as a special internal state of the freedom from envy. This state includes a harmonious, calm internal structure with a lack of desire not only to redistribute a resource in their favor, but also with the formation of skills from "not grieve about the success of other" to "joy from the success of another". The ethical basis of aphthony is defined by such components as benevolence, gratitude, compassion and common gladness, respect for others, generosity, the ability to be satisfied that you have.

The analysis of concept "aphthony" taking into account its origin from the religious-ethical sphere of East-European culture and marking its impossibility without participation by personality allowed to take step from a patristic inheritance to the modern educational tasks. Are proposed some philosophical-educational directions for the forming of the aphthony that are offered in the condition of educational experiment by: 1) including of philosophical and worldview educational constructs of the struggle against envy; 2) mastering of the spiritually values sense of aphthony by culturally centric education; 3) introduction of a religious-humanistic approach to the teaching of Christian-ethical courses with their doctrine about overcoming of envy. All marked directions allow to spread aphthony from the theoretical plane to space of life's building. Certainly, that formation of the ethical concept of aphthony by the facilities of culturally centric education is appeared more effective in comparing to two other directions of experimental research.

Key words: envy, values, spiritual development, growing personality, educational experiment. 